\title{
表面プラズモン共鳴とそのレーザー顕微鏡への応用
}

岡本 隆之*・山口 一郎*

\author{
（1996年 7 月 11 日 受理）
}

\section{Surface Plasmon Resonance and Its Application to Laser Microscopy}

\author{
Takayuki OKAMOTO* and Ichirou YAMAGUCHI*
}

(Received July 11, 1996)

\begin{abstract}
Surface plasmons are electromagnetic waves localized and propoagating along metal-dielectric interfaces. They can be excited by a $p$-polarized light in an attenuated total reflection geometry. The surface plasmon resonance can be used in laser microscopy that provides two dimensional maps of refractive index and/or thickness of samples with very high sensitivity. Spatial light modulators using the surface plasmon resonance are also described.
\end{abstract}

Key Words: Surface plasmon, Microscopy, ATR, Thin film, Evanescent wave

1.はじめに

表面プラズモンとは金属/誘電体界面に局在 し，界面に沿って伝搬する電磁波で，金属表面 での電荷密度波を伴うものである。1968 年に Otto ${ }^{1)}$ により, つづいて, Kretschmann and Raether ${ }^{2)}$ により，全反射光学系を用いた光による 表面プラズモンの励起法が考案された。それ以 来, この表面プラズモン共鳴の現象は, 数々 の, 表面や薄膜に関する研究に利用されてきた。 しかしながら，顕微鏡へ応用されたのは比較的最 近で，1987年から 1988年にかけて，Yeatman and $\mathrm{Ash}^{3-5)}$ および, Rothenhäuslerら ${ }^{6-8)}$ によって報告さ れたのが最初である。前者は厚さ $0.7 \mathrm{~nm} の \mathrm{WO}_{3}$ 薄 膜の格子を, 後者は厚さ $9.3 \mathrm{~nm}$ の $\mathrm{SiO}_{\mathrm{x}}$ 薄膜や, 4
層のLangmuir-Brodgett(LB) 膜などの膜厚分布を観 察している。表面プラズモン顕微鏡は金属表面上 の薄膜層や，吸着層などの存在に対して非常に敏 感であり, それらの膜厚や屈折率に関する2次元 情報が高感度で得られるという特長を持つ。

本解説では最初に，表面プラズモンおよび表 面プラズモン共鳴について説明し, 次に表面プラ ズモン顕微鏡とその具体的な装置, 観察例につい て述べる。また，表面プラズモン顕微鏡の応用の 1つである空間光変調素子についても紹介する。

\section{2. 表面プラズモン共鵬}

2.1 1表面プラズモンとその存在条件 ここで述べる表面プラズモンとは2つの媒質が

* 理化学研究所 ( ₹ 351-01 埼玉県和光市広沢 2-1)

* The Institute of Physical and Chemical Research (RIKEN) (2-1 Hirosawa, Wako, Saitama 351-01) 
平面で接しているとき，その界面に局在し，そ の界面に沿って伝搬する電磁波をいう。まず, このような電磁波が存在するためには，それぞ れの媒質にどのような条件が必要かを考える。 媒質 $1(\mathrm{z} \geq 0)$ と媒質 $2(\mathrm{z} \leq 0)$ が界面 $(\mathrm{z}=0)$ で接して いる状態を考える。界面に沿って $\mathrm{x}$ 方向に伝搬 し, 界面から離れるにしたがって減衰する電磁 波の場のy方向成分は，それぞれの媒質中で次の ように与えられる。

$$
\begin{aligned}
& U_{1}=U_{0} \exp \left[i\left(k_{x} x-\omega t\right)\right] \exp \left(-\gamma_{1} z\right) \quad \text { for } z \geq 0 \\
& U_{2}=U_{0} \exp \left[i\left(k_{x} x-\omega t\right)\right] \exp \left(\gamma_{2} z\right) \quad \text { for } z \leq 0
\end{aligned}
$$

ここで，UはTE波の場合は電場を指し，TM波の 場合は磁場を差す。また， $k_{x}$ は波数の接線成分で

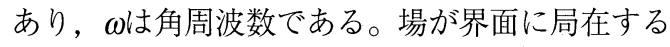
ためには $\gamma_{1} お よ ひ ゙ \gamma_{2}$ たもに正の実数である必要 がある。これらの場は界面で境界条件を満足し なければならない。すなわち, 電場, 磁場の接 線成分が連続で, かつ, 電束密度, 磁束密度の 法線成分が連続でなければならない。式(1)はす でに前者を満足している。後者に関しては，

$$
\begin{aligned}
& \frac{1}{\varepsilon_{1}} \frac{\partial U_{1}}{\partial z}=\frac{1}{\varepsilon_{2}} \frac{\partial U_{2}}{\partial z} \quad \text { for TM wave } \\
& \frac{\partial U_{1}}{\partial z}=\frac{\partial U_{2}}{\partial z} \quad \text { for TE wave }
\end{aligned}
$$

となる，ここで， $\varepsilon_{1} ， \varepsilon_{2}$ はそれぞれ媒質 1 , 媒質 2 の誘電率である。TM波の場合, 式(2)より次の 条件が導かれる。

$$
\frac{\varepsilon_{1}}{\varepsilon_{2}}=-\frac{\gamma_{1}}{\gamma_{2}}
$$

ここから，2つの媒質のうち一方の誘電率は負で なければならないことがわかる。また，両媒質 への侵入長 (振幅が1/eになる界面からの距離) は $\gamma$ の逆数で与えられるため, 誘電率に反比例するこ とがわかる。一方TE波の場合，式(3)より $\gamma_{1}=-\gamma_{2}$ となり，最初に述べた $\gamma_{1}$ およ゙的はともに正の実 数であるという条件と矛盾する。したがって, TE波の表面プラズモンは存在しないことがわか る。この帰結は表面プラズモンの本来の意味を
考えれば明らかである。すなわち, 表面プラズ モンとは界面に沿って伝搬する表面電荷密度波 と電磁波が結合したものであるため，もともとy 方向の電場成分を持たないからである。式(4)と 両媒質での電磁波の分散関係

$$
k_{x}^{2}-\gamma_{i}^{2}=\varepsilon_{i}\left(\frac{\omega}{c}\right)^{2} \quad \text { for } i=1,2
$$

から，表面プラズモンの分散関係

$$
k_{x}=\left(\frac{\omega}{c}\right)\left(\frac{\varepsilon_{1} \varepsilon_{2}}{\varepsilon_{1}+\varepsilon_{2}}\right)^{1 / 2}
$$

が得られる。ここで，cは真空中の光速である。

さて,いくつかの金属の誘電率の実部は可視 域で負であり，式(4)の条件を満たす。しかし， 金属の誘電率は虚部を持つため, 表面プラズモン は界面に沿って伝搬しながら減衰する。今, 媒質 1 が複素誘電率 $\varepsilon_{1}=\varepsilon_{1}^{\prime}+i \varepsilon^{\prime \prime}$ を持つ金属であるとす ると, 表面プラズモンの波数も複素数 $k_{x}=k_{x}^{\prime}+i k_{x}{ }_{x}$ となり次式で与えられる。

$$
\begin{aligned}
& k_{x}^{\prime}=\left(\frac{\omega}{c}\right)\left(\frac{\varepsilon^{\prime}{ }_{1} \varepsilon_{2}}{\varepsilon^{\prime}{ }_{1}+\varepsilon_{2}}\right)^{1 / 2} \\
& k^{\prime \prime}{ }_{x}=\left(\frac{\omega}{c}\right)\left(\frac{\varepsilon^{\prime}{ }_{1} \varepsilon_{2}}{\varepsilon^{\prime}{ }_{1}+\varepsilon_{2}}\right)^{3 / 2}\left[\frac{\varepsilon^{\prime \prime}}{2\left(\varepsilon^{\prime}\right)^{2}}\right]
\end{aligned}
$$

式(8)より, 表面プラズモンの伝搬長, すなわ ち, その強度が伝搬にともない $1 / e$ にる距離が 求まり, 次式で与えられる。

$$
L=\left(2 k^{\prime \prime}{ }_{x}\right)^{-1}
$$

\section{2光による表面プラズモンの励起}

表面プラズモンは最初に定義したように，両 媒質で界面から離れるにしたがって指数関数的 に減衰する。そのため, 表面プラズモンは非放 射である。逆にいえば，外からの伝搬光で，表 面プラズモンを励起することはできない。式(7) からもわかるように, 表面プラズモンの波数は 両媒質中の伝搬光の波数よりも大きい。すなわ ち, 表面プラズモンは両媒質でエヴァネッセン ト波となっている。逆に考えれば，エヴァネッ セント波により表面プラズモンを励起すること 
(a)

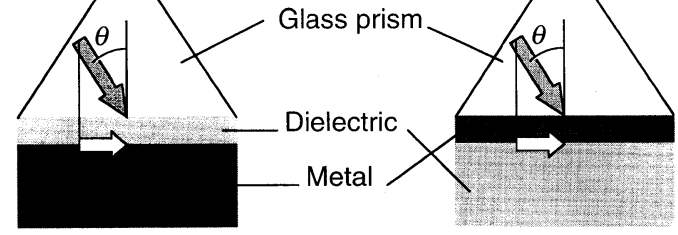

$\Longrightarrow$ Wave vector of $p$-polarized light

$\Longrightarrow$ Wave vector of surface plasmon

Fig. 1 (a) Otto and (b) Kretschmann configurations for excitation of surface plasmon.

ができる。エヴァネッセント波を得る最も簡単 な方法は減衰全反射 (Attenuated Total Reflection: ATR) 法を用いることである。Otto ${ }^{1)}$ はFig. 1 (a)に 示すように誘電体側からプリズムを界面に近付 け，プリズム側から臨界角以上の角度で $\mathrm{p}$ 偏光 (TM波)単色光を入射し，その時に生じるエヴァ ネッセント波で表面プラズモンを励起する系を 考案した。しかしながら，このOtto配置はプリズ ムと金属表面との距離を数 $10 \mathrm{~nm}$ に制御しなけれ ばならないのと，金属表面上の試料の厚さに制 限を受けるため，顕微鏡には次に述べる Kretschmann配置 ${ }^{2,9)}$ が適している。この系では Otto配置とは逆に，Fig. 1(b)に示すようにプリズ 厶を金属側から界面に近付ける方法である。実 際にはプリズムの底面に，金属薄膜を真空蒸着 することで，この系は簡単に実現できる。ま た，この系では金属表面上の試料の厚さに制限 を受けないため，ほとんどの表面プラズモン顕 微鏡ではこの Kretschmann配置が用いられてい る。

これらの配置においては，エヴァネッセント 波の波数と，表面プラズモンの波数 $k_{\mathrm{x}}$ が一致した とき，すなわち，プリズムの屈折率を $n_{0}$, 入射角 を $\theta_{0}$ とすると，

$$
k_{x}^{\prime}=\left(\frac{\omega}{c}\right) n_{0} \sin \theta_{0}
$$

のとき，表面プラズモンが励起され共鳴が起き る。表面プラズモン共鳴は反射率を観測するこ とで確認できる。Kretschmann配置における振幅 反射率 $r_{012}$ は次式で与えられる。

$$
r_{012}=\frac{r_{01}+r_{12} \exp \left(2 i k_{\mathrm{zl}} d\right)}{1+r_{01} r_{12} \exp \left(2 i k_{\mathrm{z} 1} d\right)}
$$

ここで， $r_{\mathrm{ij}}$ は媒質 $\mathrm{i} /$ 媒質 $\mathrm{j}$ 界面における振幅反射率 であり(媒質0はプリズム)， $k_{\mathrm{z} 1}$ は媒質1(金属)に おける波数の垂直成分である。入射角を走査し ながら反射率を測定すると，共鳴角 $\theta_{0}$ において反 射率が急激に減衰する現象 (ディップ)が見られ (以後，ディップが示された反射率の角度分布を 共鳴曲線と呼ぶ)，この入射角において表面プラ ズモン共鳴が起きていることが確認できる。す なわち，入射光のエネルギーが表面プラズモン に与えられ，最終的に熱として消費されてい る。

\section{3 共鳴曲線}

ディップの深さは，入射光エネルギーの表面 プラズモンへの変換率で決まる。表面プラズモ ンの伝搬に伴う減衰は，金属での吸収による内 部損失と，一度励起された表面プラズモンが再 びプリズム側に光を放射するために起こる放射 損失による。後者は励起にATR 法を用いたこと に起因する。Kretschmann配置において，金属膜 が厚い場合，入射波はほとんどプリズム/金属界 面で反射され，表面プラズモンの励起に関与し なくなるため,ディップは浅くなる。また，金 属膜が薄い場合，放射損失が大きくなりやはり ディップは浅くなる。金属膜厚が適当で，再放

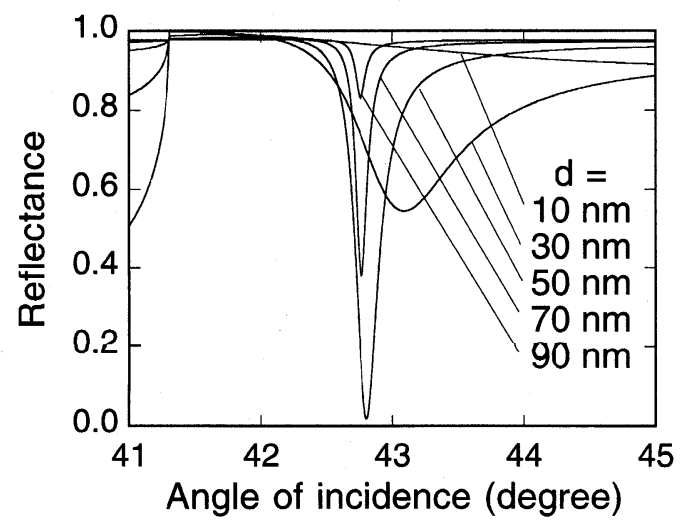

Fig. 2 Resonance curves for different thicknesses $d_{1}$ of silver films in the Kretschmann configuration. 


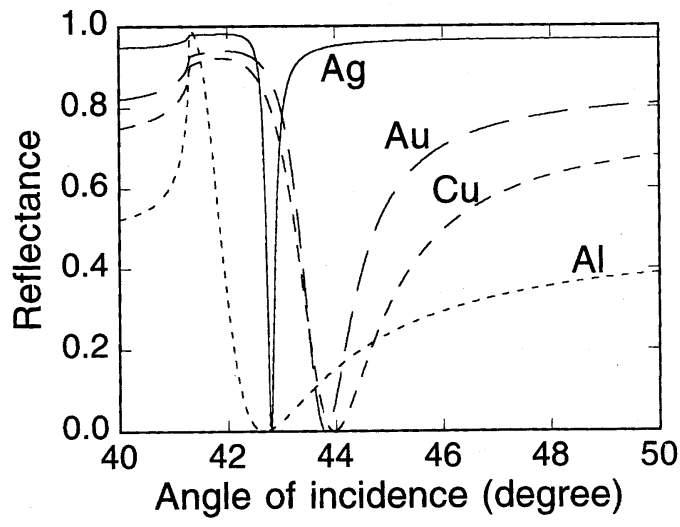

Fig. 3 Resonance curves for silver, gold, copper, and alminium films. The thicknesses of them are chosen to minimize the reflectance at the dips and summarized in Table I.

Table I Indices of refraction of metals and their thick ness to give minimum refectance ${ }^{24,25)}$.

\begin{tabular}{ccc}
\hline \hline & Index of refraction & Thickness $(\mathrm{nm})$ \\
\hline Silver & $0.06+4.28 i$ & 53.1 \\
Gold & $0.18+3.44 i$ & 47.9 \\
Copper & $0.27+3.41 i$ & 42.4 \\
Aluminium & $1.37+7.62 i$ & 8.57 \\
\hline \hline
\end{tabular}

射光とプリズム/金属界面での反射光の振幅が等 しくなったとき(このとき両者の位相は $\pi$ たけ異 なっている)ディップは最も深くなる。Fig. 2にプ リズム/銀/空気の系において, 銀の膜厚を変化さ せたときの共鳴曲線を示す。励起光はHe-Neレー ザー(波長 $\lambda=632.8 \mathrm{~nm}$ ), プリズムはBK-7 (屈折率 $\left.n_{0}=1.515\right)$ を仮定している。膜厚 $50 \mathrm{~nm}$ 付近で, 最 もディップが深くなっているのがわかる。

一方，ディップの幅は表面プラズモンの伝搬 長に逆比例する。これは, スペクトル幅が波連 の長さに逆比例するのと同じ関係である。金属 の厚さが半無限の場合の伝搬長は式 (9)で与えら れるが，Kretschmann配置の場合，放射損失が存 在するため，伝搬長はそれよりも短くなる。そ の結果, 金属薄膜が薄くなるほど放射損失が大 きくなり，ディップ幅は広くなる (Fig. 2参照)。 デイップの反射率が0となったとき，放射損失と 内部損失は等しくなっている10)。このときの伝
搬長は式 $(9)$ で与えられる伝搬長の $1 / 2$ となる。 Fig. 3に種々の金属薄膜を用いたときの共鳴曲線 を示す。金属薄膜の厚さはディップにおける反 射率が0になるように選んでいる。このときの各 金属の複素屈折率㧍よび，膜厚をTable1に示す。 金属薄膜として，銀を選んだときに最も狭い ディップが得られることがわかる。この理由は 銀が最も小さい複素誘電率の虚部を持つためで ある。

\section{4 共鳴曲線の意味}

さて，表面プラズモン共鳴から何がわかるか について考える。式(6)および(7)より，一方の 媒質の誘電率が既知であれば，共鳴角を測定す ることにより，もう一方の媒質の誘電率を知る ことができる。しかし，表面プラズモン共鳴の 大きな特長は, バルクの屈折率の測定だけでは なく, 薄膜の屈折率や膜厚が測定できることで ある。最初に述べたように, 表面プラズモンで は界面において，場の振幅が最も大きくなる。 したがって, 表面プラズモン共鳴は界面付近の 状態の変化に, 非常に敏感である。ここで媒質 1 と媒質 2 の間に誘電率 $\varepsilon_{3}$, 膜厚 $d_{3}$ の薄膜層が存在 する場合を考える。膜厚 $d_{3}$ が波長に比べて十分小 さい場合, Kretschmann ${ }^{9}$ によって表面プラズモ ンの波数ベクトルの $k_{\mathrm{x}}$ 一次近似式が次のように与 えられている。

$$
\hat{k}_{x}=k_{x}+\Delta k_{x}
$$

ここで,

$$
\Delta k_{x}=\left(\frac{\omega}{c}\right)\left(\frac{\varepsilon_{3}-\varepsilon_{2}}{\varepsilon_{3}}\right)\left(\frac{\varepsilon^{\prime} \varepsilon_{2}}{\varepsilon_{1}^{\prime}+\varepsilon_{2}}\right)^{2}\left(\frac{\varepsilon_{3}-\varepsilon_{1}^{\prime}}{\varepsilon_{2}-\varepsilon_{1}^{\prime}}\right)\left(-\varepsilon_{1}^{\prime} \varepsilon_{2}\right)^{-1 / 2}\left(\frac{2 \pi d_{3}}{\lambda}\right)(13)
$$

さらに高次の近似式は Pockrand ${ }^{11)} に よ り$ 求めら れている。この式より，膜厚が波長に比べて十 分薄い場合, 波数ベクトルの変化は膜厚に比例 することがわかる。したがって, 各媒質の誘電 率が既知であれば, 共鳴角から薄膜の厚さを得 ることができる。また逆に，膜厚が既知であれ ば，誘電率が得られる。Fig. 4にプリズム/銀 / $\mathrm{SiO}_{2} /$ 空気の系における共鳴曲線を示す。 $\mathrm{SiO}_{2}$ の 膜厚が厚くなるにしたがって, 共鳴角が大きく なっていくことがわかる。これらの共鳴曲線か 


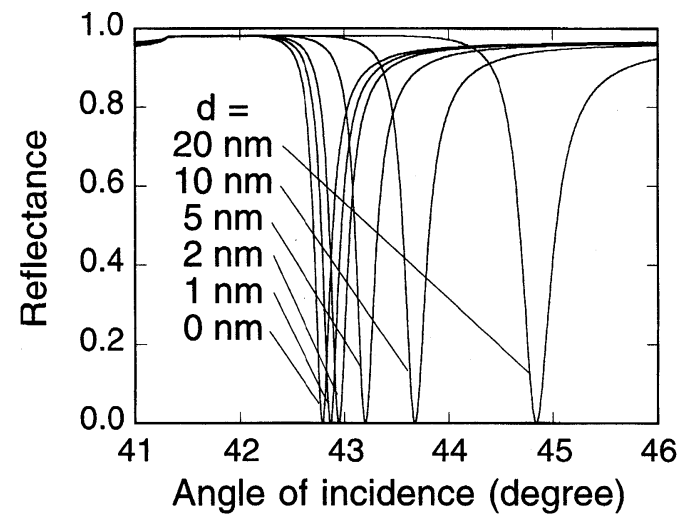

Fig. 4 Resonance curves for silver covered with $\mathrm{SiO}_{2}$ of different thicknesses $d_{3}$.

ら, $0.1 \mathrm{~nm}$ 程度の膜厚分解能は容易に得られるこ とが理解できる。

\section{3. 表面プラズモン顕微鏡}

\section{1 原理}

表面プラズモン顕微鏡は, 表面プラズモン共 鳴を用いて, 膜厚や屈折率の2次元分布を観察す る顕微鏡である。Fig. 5に代表的な表面プラズモ ン顕微鏡の光学系を示す。表面プラズモンはコ リメートされた $\mathrm{p}$ 偏光レーザー光によって励起さ れる。反射光は顕微鏡対物レンズによりスク リーンまたはカメラ上に拡大し結像される。本 顕微鏡において入射角は共鳴角付近に固定され る。したがって, 屈折率分布による共鳴角の変 化は，反射率分布に変換され，最終的には像の 明暗として得られる。このとき，像のコントラ ストは共鳴曲線の傾きが大きいほど，すなわ ち，ディップの幅が狭いほど高くなる。した がって, Fig.3からわかるように，銀が最も良い 感度を与える。ただし, 銀は化学的に不安定で あるため，コントラストを犠牲にしても，金が 用いられることも多い。

空間分解能は通常の光学顕微鏡では, 対物レ ンズの回折限界で決まるが, 表面プラズモン顕 微鏡の場合, それに加えて, 表面プラズモンの 伝搬長を考慮に入れなければならない。すなわ ち入射面と垂直方向の分解能は回折限界で与え られ, 入射面と平行な方向の分解能は表面プラ

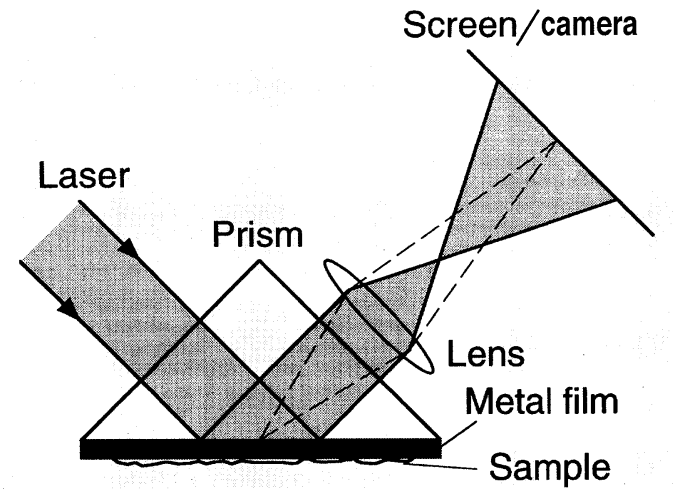

Fig. 5 Typical optical configuration of the surface plasmon microscopy.

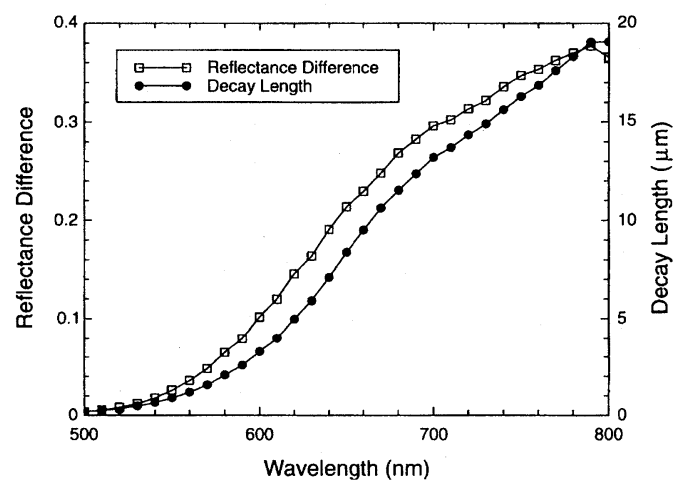

Fig. 6 Reflectance difference for bare gold and gold covered with $2.5 \mathrm{~nm} \mathrm{SiO} 2$ (circles) and propagation length of surface plasmon (squares) as a function of wavelength. ${ }^{12)}$

ズモンの伝搬長で与えられる。このことは Berger ら12)によって実験で確認されている。したがっ て, 空間分解能を上げるためには, 伝搬長を短 くすればよい。伝搬長は銀に比べて金の方が, また, 可視域では短波長の方が短くなる。問題 は伝搬長が短くなるほどディップの幅が広くな るため, 得られる像のコントラストが減少する ことである。そのため実際には，必要以上に伝 搬長を短くすることは得策ではない。Fig. 6は金 の表面に厚さ $2.5 \mathrm{~nm}$ の $\mathrm{SiO}_{2}$ 薄膜をコートした場合 としない場合とで得られる反射率の差と表面プ ラズモンの伝搬長を, 励起光の波長の関数とし て表したものである12)。Bruijn ら ${ }^{13)}$ は試料を面内 で回転させることにより，675nmの波長において 銀を用いて $1.5 \mu \mathrm{m}$ の分解能を得ている。 


\section{2 定量測定}

今までの顕微鏡では，共鳴角の入射角からの ずれ量を，反射光強度の形で得るものであっ た。この方法は膜厚などの分布を2次元の明暗画 像として，一度に観察できる特長がある。反射 率分布から膜厚分布を定量的に求めているもの もあるが14)，この方法は入射光の強度むらな ど，雑音の影響を受けやすく，定量的な測定に は不向きである。Hickel and Knol1 ${ }^{15)}$ は入射角を $0.4^{\circ}$ ずつ変えて撮影した8枚の画像の，暗線をプ ロットすることで，膜厚の分布を等高線で表し た。この方法は観察領域に扔いて, 膜厚の変化 が単調なときには適用できるが，変化が複雑に なると適用困難になる。

著者らは, 試料の各点で, 反射光強度の角度分 布を測定することで，共鳴角の2次元分布が得ら れる表面プラズモン顕微鏡を開発した16)。Fig. 7 に光学系を示す。レーザー光を顕微鏡対物で試 料上に集光し，その反射光を1次元のイメージセ ンサーで受光している。イメージセンサでは試 料の一点からの反射光の角度分布が，機械的走 査なしに得られ，共鳴角を正確に求めることが できる。試料とプリズムを一体にして2次元走査 することにより，共鳴角のマッピングができ， そこから, 屈折率分布や, 膜厚分布が定量的に 得られる。Fig. 8に本顕微鏡により測定したガラ ス基板に埋め込まれた光導波路の断面の屈折率 分布を示す。試料表面に直接厚さ $55 \mathrm{~nm}$ の銀薄膜 を真空蒸着し，イマージョンオイルを介して， 高屈折率プリズム $(\mathrm{n}=1.879)$ に密着させた。本顕 微鏡では $10^{-4}$ 以下の屈折率分解が得られている。 もう1つの例として，LB 膜のモルフォロジーを

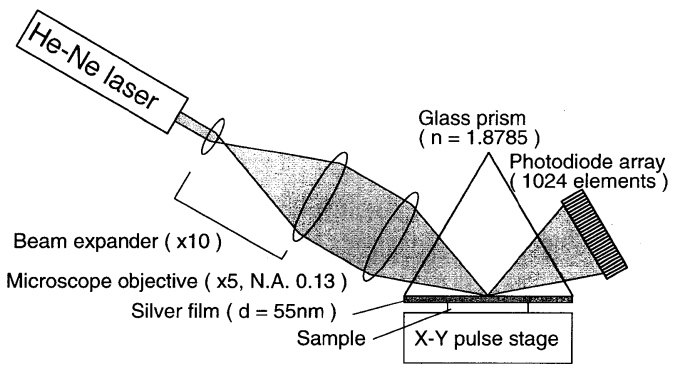

Fig. 7 Surface plasmon microscope with an electronic angular scanning. ${ }^{16)}$

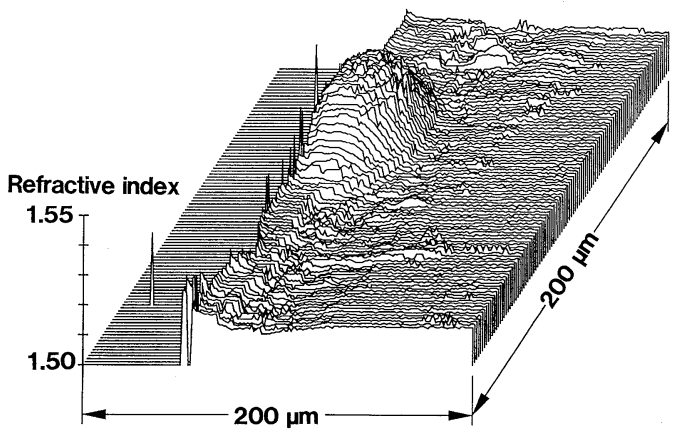

Fig. 8 Two-dimensional distribution of refractive index of an optical waveguide. ${ }^{16)}$

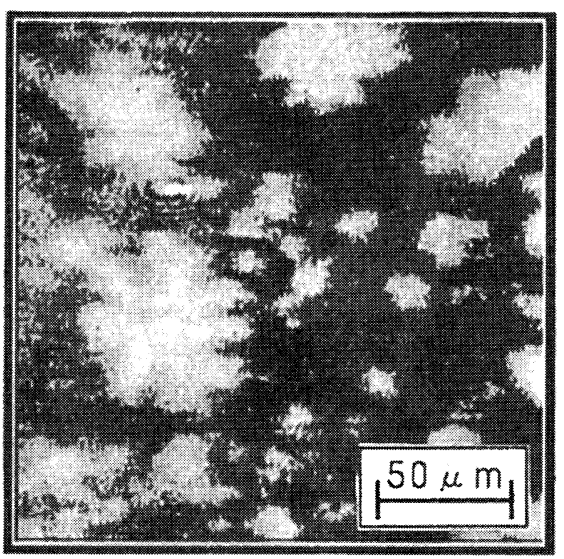

(a)

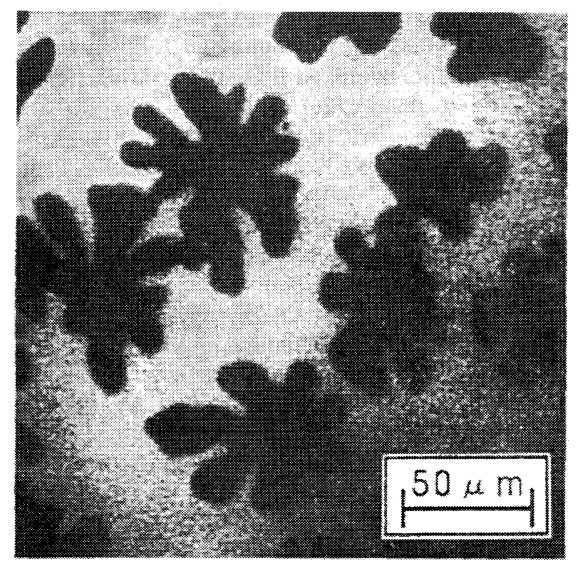

(b)

Fig. 9 Images of didodecylphosphate monolayers (a) deposited on gold covered with a polyimide monolayer observed with the surface plasmon microscope and (b) deposited on a glass surface observed with a fluorescence microscope. ${ }^{17)}$ 
観察した結果を示す。水面上の単分子膜は表面 圧が大きくなるにしたがって，気体相から流動 相をへて, 結晶相へと相変化する。流動相と結 晶相が混在するジドデシルリン酸の単分子膜 を，ポリイミド膜を1層コートした厚さ45nmの金 薄膜上に堆積し，それを観察した結果をFig. 9(a) に示す17)。明るい部分が結晶相で, 流動相に比 較して，0.071共鳴角が大きくなっている。Fig. 9 (b)に比較のために色素をドープした同じLB膜の 蛍光顕微鏡像を示す。結晶相では色素がはじき だされて, 蛍光が得られていない。しかし, 表 面プラズモン顕微鏡では色素をドープすること なく高感度で相状態の分布像が得られている。

\section{4. 空間光変調素子への応用}

表面プラズモン顕微鏡は誘電体の屈折率分布 をコントラストに変換する。したがって，なん らかの方法で, 誘電体の屈折率分布を自由に変 化させることができれば，表面プラズモン顕微 鏡はそのまま空間光変調素子になる。Yeatman and Caldwell ${ }^{18)}$ は機能性媒質としてのネマチック 液晶に格子状の電極で電圧をかけ, 屈折率分布 を与えることで，空間光変調素子を開発した。 その後, 彼らは光導電性薄膜であるアモルファ スシリコンを格子電極と置き換えることで, 光 書き込み型の空間光変調器を実現している19)。 著者らは機能性媒質として, 色素ドープ高分子 を用いた全光型の空間光变調素子を提案した20)。 Fig. 10に光学系の概念図を示す。高屈折率プリズ ムに真空蒸着した銀薄膜に, 厚さ $10 \mu \mathrm{m}$ 程度のメ

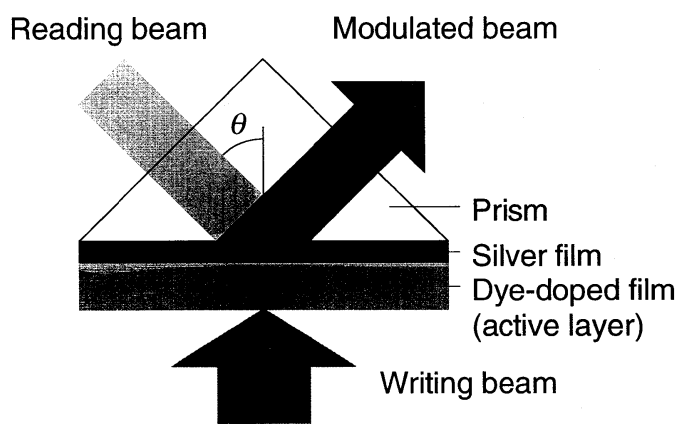

Fig. 10 Schematic diagram of the spatial light modulator using surface plasmon resonance. ${ }^{20)}$

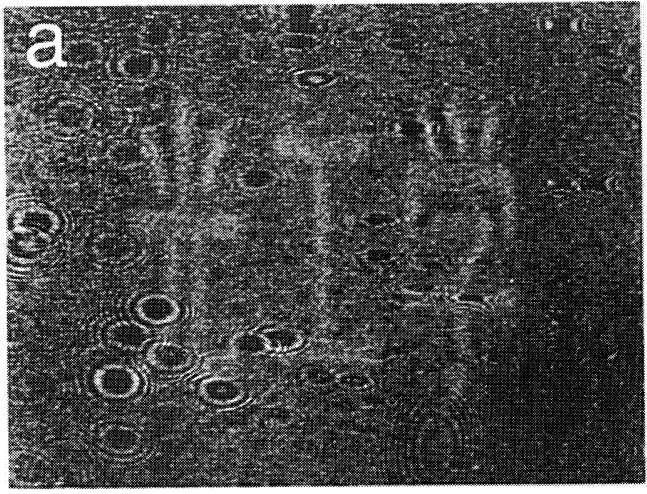

\section{$2 \mathrm{~mm}$}

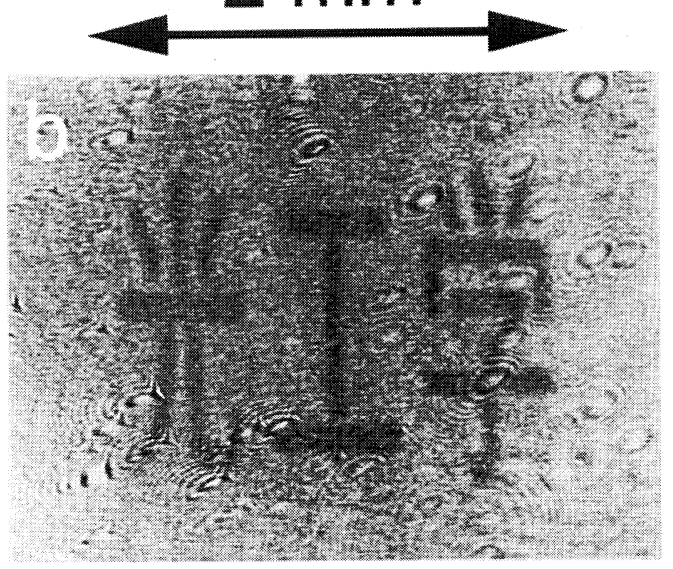

Fig. 11 Output images read out with (a) positive and (b) negative contrast modulation. ${ }^{20)}$

チルオレンジをドープしたポリビニルアルコー ルをコートしただけの簡単な構造となってい

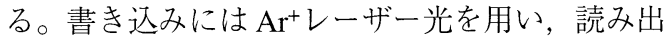
しには He-Ne レーザー光を用いている。Fig. 11 に読みだされた画像を示す。Fig. 11 (a) は書き込 み光が照射されていない部分に対する共鳴角に 入射角を一致させている場合で，正のコントラ ストが得られている。また，Fig. 11(b)では反対 に，書き込み光が照射されている部分に対する 共鳴角に入射角を一致させた場合で，コントラ ス卜反転した像が得られる。このように本変調 素子では，入射角を共鳴角の周りでわずかに変 化させるだけで，コントラストを正負自由に選 ぶことができる。なお, 光照射における色素 ドープ高分子の屈折率変化は- $8.62 \times 10^{-4} \mathrm{~cm}^{2} / \mathrm{W}$ 
で，主として光吸収による温度変化によるもの であることを確認している。

\section{5. おわりに}

表面プラズモン顕微鏡の原理，特長，応用に ついて述べた。表面プラズモン顕微鏡は試料を 金属上に固定しなければならないという制約が あるが，単分子膜の膜厚変化(または屈折率変 化)が感度良く観察できることからわかるよう に，界面付近の情報を2次元的に得る手段として は非常に優れた方法である。

表面プラズモン顕微鏡で得られるデー夕は基 本的に，共鳴角だけである。バルク試料の測定 においては未知変数は屈折率だけであり, 容易 に求まる。しかし，薄膜試料の場合には，一般

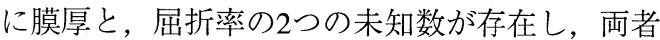
の分離測定は困難である。今後，多波長を利用 するなどして，両者を分離して観察できるよう になることが望まれる。

なお，最近の話題として，表面プラズモン共 鳴と走査型トンネル顕微鏡を組み合わせて，銀 薄膜の表面や，それに吸着させた色素クラスター などが数nmの空間分解能で観察されている21-23) ことを付記しておく。このように，エヴァネッ セント波を用いた光学技術に新しい展開をもた らす可能性も見えているので, 微細構造の解析 技術としての今後が期待される。

\section{参 考 文 献}

1) A. Otto: Z. Physik. 216 (1968) 398.

2) E. Kretschmann and H. Raether: Z. Naturfors. 23a (1968) 2135.

3) E. Yeatman and E. A. Ash: Electron. Lett. 23 (1987) 1091.

4) E. M. Yeatman and E. A. Ash: Proc. SPIE 897 (1988) 100.

5) E. M. Yeatman and E. A. Ash: Proc. SPIE 1028 (1988) 231.

6) B. Rothenhäusler, C. Duschl, and W. Knoll: Thin
Solid Film 159 (1988) 323.

7) B. Rothenhäusler and W. Knoll: Nature 332 (1988) 615.

8) B. Rothenhäusler and W. Knoll: J. Opt. Soc. Am. B5 (1988) 1401.

9) E. Kretschmann: Z. Physik. 241 (1971) 313.

10) H. Raether: Surface plasmons on smooth and rough surfaces and on gratings (Springer-Verlag, Berlin, 1988).

11) I. Pockrand: Surf. Sci. 72 (1978) 577.

12) C. E. H. Berger, R. P. H. Kooyman, and J. Greve: Rev. Sci. Instrum. 65 (1994) 2829.

13) H. E. de Bruijn, R. P. H. Kooyman and J. Greve: Appl. Opt. 32 (1993) 2426.

14) H. Morgan and D. M. Taylor: Appl. Phys. Lett. 64 (1990) 1330

15) W. Hickel and W. Knoll: Appl. Phys. Lett. 57 (1990) 1286.

16) T. Okamoto and I. Yamaguchi: Opt. Commun. 93 (1992) 265.

17）田島信芳，近藤聖二，篠原悦夫，越石喜代 三，岡本隆之，山口一郎，下村政嗣: 分光研 究 42 (1993) 156.

18) E. M. Yeatman and M. E. Caldwell: Appl. Phys. Lett. 55 (1989) 613.

19) M. E. Caldwell and E. M. Yeatman: Appl. Opt. 31 (1992) 3880.

20) T. Okamoto, T. Kamiyama and I. Yamaguchi: Opt. Lett. 18 (1993) 1570.

21) M. Specht, J. D. Pedarnig, W. M. Heckl and T. W. Hänsch: Phys. Rev. Lett. 68 (1992) 476.

22) J. D. Pedarnig, M. Specht, W. M. Heckl and T. W. Hänsch: Appl. Phys. A55 (1992) 476.

23) Y-K. Kim, P. M. Lundquist, J. A. Helfrich, J. M. Mikrut, G. K. Wong, P. R. Auvil and J. B. Ketterson: Appl. Phys. Lett. 66 (1995) 3407.

24) P. B. Johnson and R. W. Christy: Phys. Rev. B6 (1972) 4370.

25) E. D. Palik (ed): Handbook of optical constants of solids (Academic Press, Orland, 1985). 